\title{
Physical Properties and Some Bioactive Compounds of Four Pomegranate Cultivars (Punica granatum L.) Grown in Egypt
}

\author{
Faten, F. Abdel-salam, Moharram, Y.G. \& Esmat, M. El-Zalaki \\ Food Science and Technology Department, Faculty of Agriculture, El-Shatby, 21545, \\ Alexandria University, Alexandria, Egypt.
}

Received: 5 March, 2018

Revised: 10 June, 2018

Accepted: 25 June, 2018

\begin{abstract}
The objective of this study was to estimate the effect of pomegranate cultivar on the physical properties and the distribution of bioactive compounds in the different parts of its fruits. Three traditional Egyptian cultivars namely, Edkawy, Manfaloty, and Sahrawy in addition to Wonderful from the recent introduced accessions. The results showed significant variations in the peels, arils and rinds percentage, length, diameter, volume of fruit and arils, calyx diameter and index, peel thickness and peel thickness index, colour measurements $\left(L^{*}, a^{*}, b^{*}\right.$ and $\left.h\right)$ of the outer peel and arils among the fruits of the four cultivars. Also, significant differences in bioactive compounds (type and content) were noted among the cultivars and the different parts of the pomegranate fruit. Edkawy fruits had the highest content of bioactive components followed by Wonderful, Manfaloty and Sahrawy, respectively. Total phenolics and total tannins were located mainly in the fruit peels while total anthocyanins and total flavonoids are concentrated in fruit arils and juice.
\end{abstract}

Key words: Pomegranate cultivar, physico-chemical properties, bioactive components, tannins, anthocyanins, phenolic compounds, flavonoids.

\section{INTRODUCTION}

Pomegranate (Punica granatum L.) is one of the oldest edible fruits in Egypt. The fruit belongs to the family Punicace. It is cultivated in semi-arid mild temperature to subtropical climate. This has led to presence of numerous unique genotypes over countries (Ismail et al., 2014). The fruit consists of persistent calyx lobes with a leathery pericarp, skin or rind overlaid with light, deep pink, or rich red colour. It is filled with numerous seeds with yellow to deep red colour and covered with pink transparent and juicy pulp (Lansky \& Newman, 2007). The acceptability of the fruits for fresh consumption and processing depends on a combination of several quality attributes relating with their physico chemical and mechanical properties such as peel colour, free of physical defects, sugar content, acidity and flavour. It is widely consumed, fresh as fresh seeds or arils, and in commercial products such as juice, jam, carbonated beverage and syrup or sherbet (Radunic et al., 2015).

Pomegranate peels are rich in polyphenols including ellagitannins, gallotannins, ellagic, gallic acids, catechins, anthocyanins, ferulic acid and querectin. These polyphenols exhibit various biological activities such as eliminating free radicals, inhibiting oxidation and microbial growth, reducing the risk of cardio-and cerebrovascular diseases and some types of cancer. Therefore, consumption of the whole fruit extracted juice will lead to intake of healthy beneficial polyphenols, than that consumption of fresh fruit arils and / or their extracted juice (Tyagi et al., 2012).

The total cultivated area, production and productivity of pomegranate in Egypt were 58319 feddan, 219663 ton, and 8.13 ton/ feddan ,respectively in year 2015 (Anonymous, 2016). There is a growing interest to increase its planting area and introduce high juice yielding new cultivars such as Wonderful to replace the old ones. Therefore, the aim of the present study was to compare between the fruit properties of three of the predominant traditional Egyptian cultivars, namely, Edkawy, Manfaloty, and Sahrawy with Wonderful, the new introduced accession to select the most promising cultivars for commercial marketing, juice processing and wastes use.

\section{MATERIALS AND METHODS}

\section{Materials:}

Thirty Kg of pomegranate (Punica granatum L.) fruits at harvesting maturity from each of four 
cultivars, namely, Edkawy, Sahrawy, Manfaloty and Wonderful, were purchased from the Central Fruits and Vegetables Market in Alexandria city. The fruits were transported and stored at $10^{\circ} \mathrm{C}$ after discarding the injured fruits in the Postharvest Technology Center, Faculty of Agriculture, Alexandria University, Egypt.

\section{Methods}

Technological methods: Pomegranate juice was extracted from the arils of the fruits. Arils were manually separated after cutting the washed fruit into four pieces and removing the fruit peel and skin covering the arils. The separated arils were mixed in an electric mixer for $30 \mathrm{sec}$. The extracted juice from the arils were filtered through muslin cloth to remove any suspended matters. The yield of juice was calculated from the extracted juices taken from $100 \mathrm{~g}$ of the separated arils from 5 random chosen fruits of each cultivar. Yield was expressed as volume of juice per 100g of fruits (Hmid et al., 2013).

Physical methods: After washing pomegranate fruits with tap water and drying at room temperature $\left(23 \pm 2^{\circ} \mathrm{C}\right)$, the mean weight of ten individual of fairly uniform size fruit of each pomegranate cultivar was calculated using Mettler Teledo AB 204 digital balance $( \pm 0.01 \mathrm{~g}$ sensitivity). The following lineal dimensions of each fruit were measured using a digital micrometer, length, equatorial diameter, calyx (sepal) diameter, and calyx length. For each dimension attribute, two measurements on opposite sides of the fruit were recorded, and the mean of 10 readings was calculated. The rapeseed solid displacement method was followed to determine the fruit volume (El-Said et al., 2009). After measuring the dimensions, the whole fruits of each cultivar were cut into four pieces and the peels, arils and rind were manually separated. The total weight of each fruit fractions was weighed to calculate the fruit weight composition. Replicate measurements of the skin thickness on opposite side were measured by a micrometer. Calyx index (CI) and peel thickness index (PTI) were calculated as mentioned by Cadze et al., (2011).

The peel and arils colour attributes in CIE.LAB coordinates $\left(\mathrm{L}^{*}, \mathrm{a} *\right.$ and $\left.\mathrm{b}^{*}\right)$ were measured along the equatorial axis of each fruit using a Minolta colorimeter (Model CR-400, Minolta,Japan) after calibration against a white tile background. Five readings of each colour index were taken per fruit colour intensity or saturation. $\mathrm{C}^{*}=\left(\mathrm{a}^{* 2+\mathrm{b}^{* 2}}\right)^{0.5}$ and Hue angle $\left(\mathrm{H}\right.$ or $\left.\tan \mathrm{b}^{*} / \mathrm{a}^{*}\right)$ were calculated.
Chemical methods: Total phenolics (TP) content was assayed by Folin-Ciocalteu reagent at $765 \mathrm{~nm}$ with tannic acid as a standard (Singleton et al., 1965) . using UV- Vis. Spectrophotometer (Laxco-Alpha-1102). Total anthocyanin content was estimated as $\mathrm{mg} / 100 \mathrm{~g}$ with a $\mathrm{pH}$ differential method using two buffer systems, potassium chloride buffer of $\mathrm{pH} 1(0.025 \mathrm{M})$ and sodium acetate buffer of pH 4.5 (0.1M ). (Ozgen et al., 2008). Total flavonoids content of pomegranate fruit were determined spectrophotometrically at a wave length of $430 \mathrm{~nm}$ using UV-Vis Spectrophotometer ( Laxco-Alpha-1102, Suite) and rutin as a standard as mentioned by Hmid et al. (2013). The method is based on the formation of a complex of flavonoid- aluminum. and the flavonoid level was expressed as $\mathrm{mg}$ of rutin equivalent per liter of juice. Total tannins content of pomegranate wastes was colourimetrically estimated at $760 \mathrm{~nm}$ as tannic acid by subtraction from total polyphenol content as described in the AOAC (2000) . using UV-Vis Spectrophotometer ( Laxco-Alpha-1102, Suite).

Statistical analysis: The obtained data from this study were analyzed using software version 917 (stats soft, Inc. USA, 2003). Analysis of variance (ANOVA) was performed to determine the differences. Differences among means were considered significant at $\mathrm{P}<0.05$ using Duncans, $\mathrm{S}$ multiple difference test (Steel \& Torrie, 1980).

\section{RESULTS AND DISCUSSION}

Weight composition and physical properties: Table (1) summarizes the weight composition and the physical properties of the fruits of the four studied cultivars. The results in this table indicate that except the fruit weight, all the other determined fruit properties differed significantly among the studied cultivars. The fruit weight ranged from 217.19 to $308.85 \mathrm{~g}$ among the four cultivars. The number of fruits per kilogram ranged from 4 to 5 in Edkawy and 3-4 in the other cultivars. Cadze et al., (2011) classified pomegranate cultivars into four grades according to their fruit weight, small (150200g), medium (201-300g), large (301-400) and extra-large (401-500g).According to this classification, the fruits of the three traditional Egyptian cultivars were considered medium while the fruits of Wonderful are large. The studies of on the Egyptian Manfaloty, Banati, Wardi, Araby, Assuity, Hegazy \& Nab-El-Gamal, generally showed that the range of weight of the fruits of these Egyptian cul- 
Table 1: Weight composition and physical properties of fruits belonging to four pomegranate cultivars

\begin{tabular}{|c|c|c|c|c|}
\hline \multirow{2}{*}{ Property } & \multicolumn{4}{|c|}{ Pomegranate cultivars } \\
\hline & Edkawy & Manfaloty & Sahrawy & Wonderful \\
\hline Fruit weight & $247.19 \pm 13.68^{\mathrm{a}}$ & $278 \pm 17.26^{a}$ & $290.84 \pm 11.72^{a}$ & $308.85 \pm 11.55$ a \\
\hline No. of fruit per Kg & 04-May & 03-Apr & 03-Apr & 03-Apr \\
\hline Peels \% & $39.79 \pm 1.26^{\mathrm{a}}$ & $37.26 \pm 1.75^{b}$ & $39.02 \pm 1.25^{\mathrm{a}}$ & $39.03 \pm 1.21^{\mathrm{a}}$ \\
\hline Arils \% & $48.88 \pm 0.76^{b}$ & $51.87 \pm 1.83^{\mathrm{a}}$ & $52.87 \pm 1.46^{\mathrm{a}}$ & $51.91 \pm 1.5^{\mathrm{a}}$ \\
\hline Rind \% & $11.33 \pm 0.81^{\mathrm{a}}$ & $10.87 \pm 0.93^{a}$ & $8.11 \pm 2.18^{b}$ & $9.06 \pm 1.74^{b}$ \\
\hline Fruit length (L) $\mathrm{cm}$ & $6.01 \pm 0.63 \mathrm{~b}$ & $10.48 \pm 0.92 \mathrm{ab}$ & $6.62 \pm 0.97 \mathrm{ab}$ & $6.81 \pm 0.63 \mathrm{a}$ \\
\hline \multicolumn{5}{|l|}{ Fruit Diameter (D) $\mathrm{cm}$} \\
\hline $\mathrm{L} / \mathrm{D}$ ratio & $11.84 \pm 0.36^{\mathrm{a}}$ & $12.56 \pm 0.72 \mathrm{ab}$ & $12.78 \pm 0.83 \mathrm{ab}$ & $13.24 \pm 0.61^{\text {a }}$ \\
\hline Fruit volume (v) $\mathrm{cm} 3$ & 0.51 & 0.52 & 0.52 & 0.47 \\
\hline Calyx length (CL) cm & $185.6 \pm 2.75^{d}$ & $214.6 \pm 1.03^{c}$ & $340.2 \pm 1.13^{\mathrm{a}}$ & $278.2 \pm 0.5^{b}$ \\
\hline Calyx index $(\mathrm{CI})^{*}$ & $1.02 \pm 0.08^{\mathrm{c}}$ & $0.93 \pm 0.01^{\mathrm{c}}$ & $1.49 \pm 0.11$ a & $1.3 \pm 0.2 \mathrm{~b}$ \\
\hline Peel thickness (PT) cm & 16.97 & 14.35 & 22.5 & 19.08 \\
\hline \multicolumn{5}{|l|}{ Peel thickness } \\
\hline index $(\mathrm{PTI}) * * \%$ & $0.32 \pm 0.02^{\mathrm{b}}$ & $0.25 \pm 0.03^{\mathrm{c}}$ & $0.36 \pm 0.03^{\mathrm{a}}$ & $0.26 \pm 0.04^{c}$ \\
\hline Arils volume & 2.78 & 1.98 & 2.81 & 1.96 \\
\hline Colour dimensional & $127.2 \pm 3.39 \mathrm{c}$ & $101.30 \pm 5.77 \mathrm{~d}$ & $212.40 \pm 0.27 \mathrm{~b}$ & $220.00 \pm 3.82 \mathrm{a}$ \\
\hline \multicolumn{5}{|l|}{ Lightness (L*) } \\
\hline Fruit & $50.13 \pm 0.37 \mathrm{~d}$ & $57.09 \pm 0.61^{b}$ & $59.04 \pm 0.38^{\mathrm{a}}$ & $54.61 \pm 0.60^{c}$ \\
\hline Arils & $31.41 \pm 0.92^{\mathrm{d}}$ & $35.45 \pm 0.61^{b}$ & $33.57 \pm 1.25^{\mathrm{c}}$ & $37.5 \pm 1.18^{\mathrm{a}}$ \\
\hline \multicolumn{5}{|l|}{ Redness $\left(a^{*}\right)$} \\
\hline Fruit & $57.21 \pm 1.4^{\mathrm{a}}$ & $50.28 \pm 0.45^{\mathrm{c}}$ & $42.63 \pm 0.69 \mathrm{~d}$ & $52.94 \pm 0.64 \mathrm{~b}$ \\
\hline Arils & $18.72 \pm 1.2^{\mathrm{d}}$ & $21.63 \pm 1.19^{\mathrm{a}}$ & $20.72 \pm 0.85^{b}$ & $19.6 \pm 1.05^{c}$ \\
\hline \multicolumn{5}{|l|}{ Yellowness (b*) } \\
\hline Fruit & $16.25 \pm 1.93 \mathrm{~d}$ & $20.96 \pm 0.4^{\mathrm{c}}$ & $26.37 \pm 1.55^{\mathrm{a}}$ & $23.49 \pm 0.35^{b}$ \\
\hline Arils & $3.99 \pm 0.54^{b}$ & $6.8 \pm 6.83^{\mathrm{a}}$ & $4.94 \pm 0.49^{b}$ & $6.25 \pm 1.04 \mathrm{a}$ \\
\hline \multicolumn{5}{|l|}{ Chroma (C) } \\
\hline Fruit & $59.49 \pm 1.52^{\mathrm{a}}$ & $53.76 \pm 0.47 \mathrm{c}$ & $48.63 \pm 0.71^{\mathrm{d}}$ & $58.18 \pm 0.43^{b}$ \\
\hline Arils & $18.95 \pm 1.09^{c}$ & $22.38 \pm 1.38^{\mathrm{a}}$ & $21.15 \pm 0.98^{b}$ & $21.78 \pm 0.32^{b}$ \\
\hline \multicolumn{5}{|l|}{ Hue angel $(\mathrm{H})$} \\
\hline Fruit & $15.76 \pm 1.79 \mathrm{~d}$ & $22.91 \pm 0.42^{c}$ & $31.89 \pm 0.65^{\mathrm{a}}$ & $21.25 \pm 0.62^{b}$ \\
\hline Arils & $10.67 \pm 0.65^{\mathrm{d}}$ & $23.10 \pm 1.95$ & $11.00 \pm 0.46$ & $17.09 \pm 0.08^{\mathrm{a}}$ \\
\hline
\end{tabular}

tivars, ranged between medium to large (250 to $400 \mathrm{~g})$. The fruits of Nab-El-Gamal had the highest weight (480 g), being extra-large. (El-Nemr et al., 1990, Humedia \& Hobani ,1993, Abd-El latif 2000, Shady 2003, El- Maghrabi 2003, Ismail et al., 2014a, Ismail et al., 2014b).

The weight composition of fruits differed significantly among the four cultivars. Peels, arils and rinds ranged from 37.26 to $39.79,48.88$ to 52.87 and 8.11 to $11.33 \%$ of the fruit weight, respectively. The lowest percentage of peels, arils and rinds were in the fruits of Manfaloty cultivar (Table 1). It was demonstrated that the edible part of the Egyptian Manfaloty pomegranate fruit was $25 \%$ of the fruit (El-Nemr et al., 1990, Abd-El-latif 2000). Meanwhile El-Maghrabi (2003), Shady (2003) and Ismail (2014) found that the flesh, seeds, and peels of fruits of Banati, Manfaloty and Wardi pome- 
granate cultivars varied from 47.7 to 62.9 and 33.81 to $52.3 \%$,respectively.. Furthermore Ismail et al., (2014) showed that the percentage of arils of the fruits of Nab-El-Gamal pomegranate cultivar was $57.87 \%$ of the fruit.

It was obvious that Edkawy fruit had lowest length (L), diameter (D) and volume (V) while, Wonderful fruits had the highest $\mathrm{L}$ and $\mathrm{D}$ and Sahrawy fruit had the highest $\mathrm{V}$. A low $\mathrm{L} / \mathrm{D}$ ratio $(0.47)$ was observed in fruits of Wonderful cultivars. The fruits of the other cultivars had nearly the same ratio (0.51-0.52) as shown in Table (1). This ratio gives an indication about the fruit shape. The fruits of the four cultivars had nearly rounded symmetrical shape . El-Nemr et al., (1990) and Abd-El-latif (2000) showed that the fruit size of Egyptian Manfaloty pomegranate cultivar was $313 \mathrm{~cm}^{3}$. Ismail et $a l .$, (2014) found that the fruit volume of Nab-ElGamal pomegranate cultivar was $416.6 \mathrm{~cm}^{3}$.

Table (1) shows that calyx diameter (0.93 to $1.49 \mathrm{~cm}$ ) varied significantly among the fruits of the studied four cultivars. It was the highest in Sahrawy fruits, having the highest $\mathrm{V}$ and $\mathrm{L} / \mathrm{D}$ ratio, followed by Wonderful and both of Manfaloty and Edkawy fruits, respectively. Calyx index (CI) varied from 14.35 to $22.5 \%$ between the fruits of the four cultivars. It was the highest in Sahrawy fruits followed by Wonderful, Edkawy and Manfaloty, respectively. According to Radunic et al., (2015), fruits with a high CI are sensitive to calyx breakage. Generally, cultivars with closed calyx are preferred because their fruits are less exposed to fungal infections in the field. Fruits of Manfaloty and Edkawy cultivars showed closed calyx index while those of Wonderful and Sahrawy had semi closed calyx index. Ismail et al., (2014) found that, calyx diameter ranged from 1.6-2.3 cm among Egyptian pomegranate cultivars.

Peel thickness (PT) varied between 0.25 to $0.36 \mathrm{~cm}$ and peel thickness index (PTI) between 1.96 to $2.81 \%$ among the fruits of the four studied pomegranate cultivars (Table 1). Manfaloty and Wonderful fruits had the lowest peel thickness (PT) and peel thickness index (PTI) compared with those of the other two cultivars. Akbarpour et al., (2009) found that the PT differed from 1.6 to 6.01 $\mathrm{mm}$ among the fruits of 20 Iranian pomegranate cultivars. Martinez et al., (2012) reported that the PT and PTI of fruits ranged from 3.6 to $4.7 \mathrm{~mm}$ and 4.2 to $5.9 \%$,respectively among pomegranate cultivars. Generally, consumers prefer pomegran- ate fruit with thin peel thickness such as Manfaloty and Wonderful fruits because they are easily peeled with low wastes.

Table (1) shows that Fruits of Wonderful cultivar had the highest arils volume $\left(220 \mathrm{~cm}^{3}\right)$ followed by those of Sahrawy $\left(212 \mathrm{~cm}^{3}\right)$, Edkawy $\left(127 \mathrm{~cm}^{3}\right)$ where Manfaloty $\left(101 \mathrm{~cm}^{3}\right)$, talked behind. Generally, increased arils volume increases the juice yield with its content of anthocyanins, (Wetzstein et al., 2011).

The colour attributes $\left(\mathrm{L}^{*}, \mathrm{a}^{*}, \mathrm{~b}^{*}, \mathrm{c}\right.$ and $\left.\mathrm{h}\right)$ of both of the whole fruits and arils differed among the four pomegranate cultivars as seen in Figs (1) and (2). The colour measurements showed that, (1-) Sahrawy fruits had the highest $L^{*}, b^{*}, h$, the lowest $\mathrm{a}^{*}$ and $\mathrm{c}$ colour attributes. It appeared as bright red yellow colour. (2-) Edkawy fruits had the highest $\mathrm{a}^{*}$, c, the lowest L, b* and $\mathrm{h}$ colour attributes. It appeared as deep red with purple. (3-) The colour of both Manfaloty and Wonderful fruits ranged from bright to vivid red with purple. (4-) Manfaloty arils had the highest $\mathrm{a}^{*}, \mathrm{~b}^{*}, \mathrm{c}, \mathrm{h}$ in addition to a satisfactory L* colour attributes. Its colour can be described as a deep red purple colour. (5-) Edkawy arils had the lowest $a^{*}, b^{*}, c, h$ and $L^{*}$ colour values. Its colour appeared as a deep red. Wonderful arils had a bright to vivid red yellow colour. (6-) Sahrawy arils had a deep dull red brown colour. Radunic et al. (2015) found that the colour of Croatian pomegranate cultivars ranged from creamy bright pink to dark red. El-Said et al. (2009) found significant fruit colour differences among the main four pomegranate cultivars grown in Saltant of Oman. Generally, pomegranate fruits with deep red colour tend to have great consumer appeals on market.

The aforementioned results agree with the finding of many studies which showed a large diversity in physical properties of pomegranate fruits among cultivars due to genotype, growing regions, climatic conditions, degree of maturity, storage conditions and agricultural practices. (Drogoudi \& Tispouridis, 2005, Fawole et al., 2012, Ferrari et al., 2014).

\section{Bioactive compounds:}

The major bioactive compounds in pomegranate fruits are polyphenols, which are mainly composed of flavonoids (flavanols, flavanons and anthocyanins) and tannins (condensed and hydrolysable tannins). The distribution of the polyphenols in the different parts of pomegranate fruit, outer peels, 

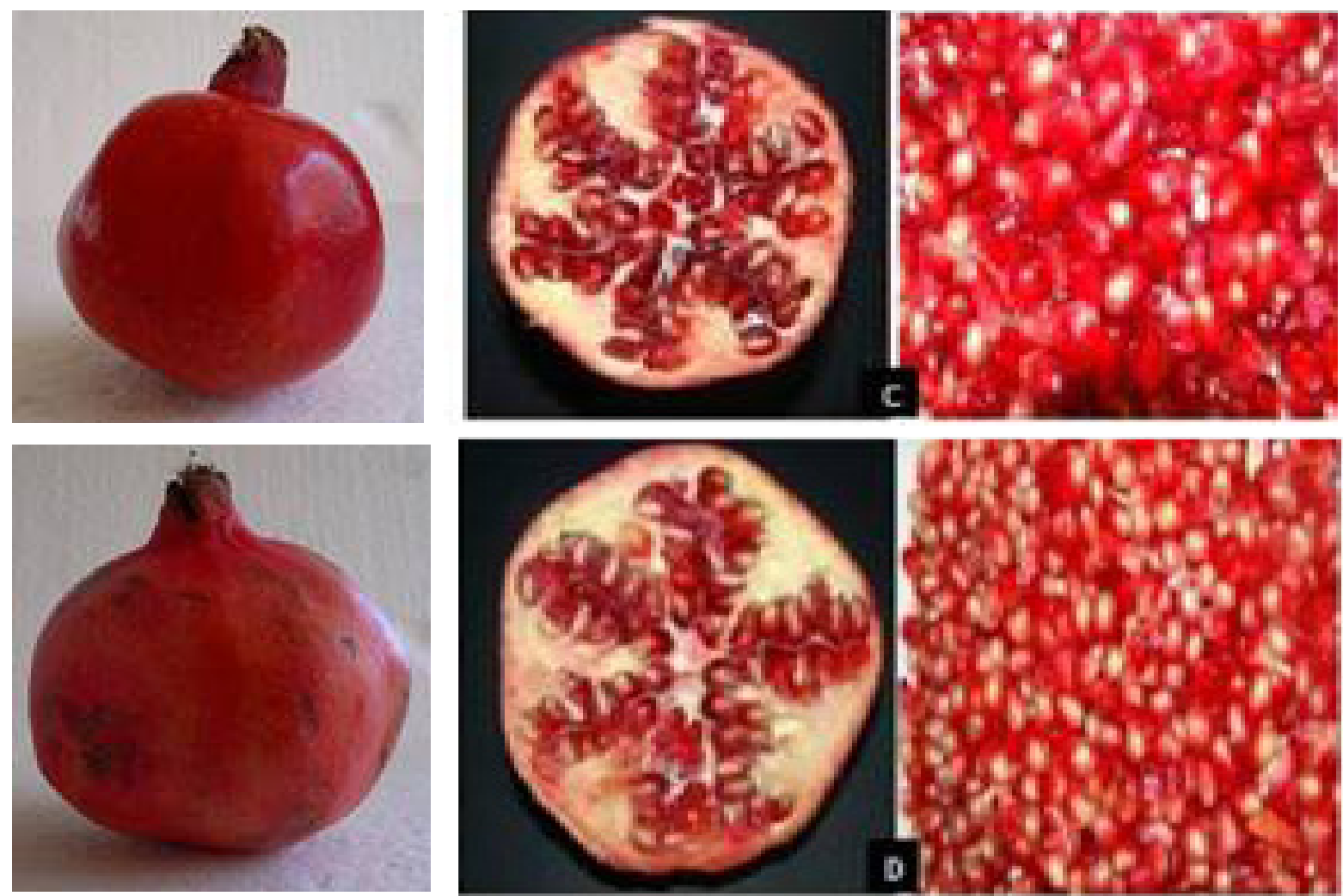

Fig 1: Appearance of whole, halves and arils of Edkawy and Manfaloty fruits.
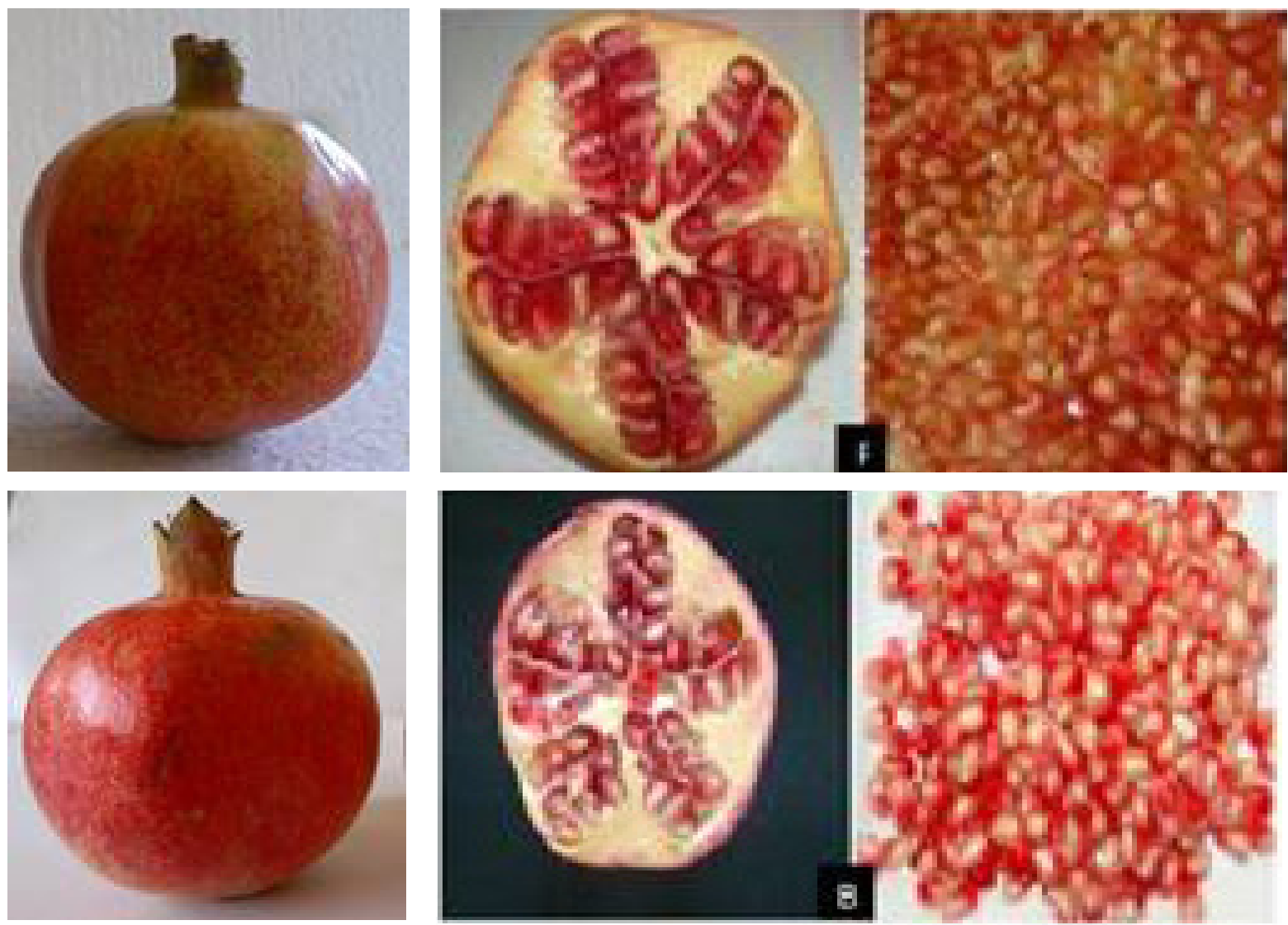

Fig 2: Appearance of whole, halves and arils of Sahrawy and Wonderful pomegranate fruits 
rinds, juice and the pith (wastes of aril juice extraction) was determined. The results show significant differences in polyphenols compounds content, due to the cultivar and the various parts of the pomegranate fruits. Edkawy fruits had the highest total phenolic and total tannins content followed by Wonderful, Manfaloty and Sahrawy ones respectively. The peels of pomegranate had the highest level of both of the two components, followed by rinds, arils, juices and pith ,respectively. The highest concentration of total flavonoids and total anthocyanins contents were found in Edkawy cultivar followed by Manfaloty, Wonderful and Sahrawy respectively. Fruit arils juice had the highest level for both components, compared with the peels, rind and pith, respectively. Patil et al., (2014) stated that pomegranate fruit is one of the rich sources of bioactive compounds including phenolic acids, tannins, flavonoids and anthocyanins. These compounds are mainly concentrated in fruit peels and mesocarp. (Mphahlele et al., 2016). They have several functions such as attracting insects, protection against UV -radiation, regulating osmotic pressure and exhibiting an astringent effect. It has also an advantageous effects on human health, as inhibiting enzymes involved in oxidation reaction or scavenging free radicals. They also influence the sensory properties of the fruits, tart taste and juice cloudiness (Viladomiu et al., 2013).

Based on the average percentage of weight composition ( $\%$ of peels, rind, juice and pith) and the mean content of the determined polyphenols compounds in various fruit parts of the four cultivars, the distribution of the bioactive components within the fruit was calculated and the results are illustrated in Figs (3), (4), (5) and (6). These figures demonstrate that the total phenolics and total tannins content were located mainly in fruit peels while the highest anthocyanins content was concentrated in the fruit juice and peels, respectively. Total flavonoids were nearly distributed at the same manner in both of fruit peels and juice. Accumulation of the various polyphenols compounds was low in both rind and pith. It can be noted that the distribution of such bioactive compounds changed according to the cultivar and the parts of the pomegranate fruits. As seen from Fig (3), peels of Manfaloty fruits accumulated lower amount of total phenolics (61\%) compared with those of the fruits of the other three cultivars (66.9-68.3\%). In contrast, the accumulation of such compounds was the highest in Manfaloty juice (21.6\%) followed by
Sahrawy (20.8\%), Wonderful (18.6\%) and Edkawy (14.4\%) juices ,respectively. These compounds were concentrated in low level in rinds of Sahrawy (3.7\%) then Wonderful (7.5\%), Manfaloty (9.2\%) and Edkawy (9.4\%) fruits,r espectively. It varied from 7.4 to $8.2 \%$ in the resulted pith from aril juice extraction. More than $55 \%$ of the total flavonoids of Wonderful fruits was concentrated in the juice. This value was 41.9, 38.3 and $31.1 \%$ in Manfaloty, Edkawy and Sahrawy juices, respectively. These polyphenols were also accumulated at levels more than $50,45,39$ and $34 \%$ in peels of Edkawy, Sahrawy, Manfaloty and Wonderful fruits respectively. Such compounds were concentrated at lower level in both of the rind and the pith, compared with juice and peels of pomegranate fruit. It was concentrated at a range of 4 to $7.5 \%$ in fruit rinds. The pith of both Edkawy and Manfaloty fruits had nearly 2 to 3 times more total flavonoids than those in Wonderful and Edkawy .

Fig (5) illustrates that also more than $70 \%$ and less than $16 \%$ of the total anthocyanins in Sahrawy pomegranate fruit were accumulated in its juice and peels, respectively. This amount was 42.1, 53.1 and $56.1 \%$ in Edkawy, Manfaloty and Wonderful juices, respectively. Peels of the last three cultivars contained more than $30 \%$ of the left total anthocyanins. Both rind and pith of Edkawy fruits had higher ratios of anthocyanins compared with those of the others three cultivars.

Total tannins were accumulated in higher levels in peels (61.6-66.9\%) than in juice (14.9-24\%), rinds (4.2-10.5\%) and pith (7.2-8.1\%) respectively (Fig 6). There was high tannins content in juice and low in rinds of Sahrawy fruit compared with those of the other three cultivars. On the other hand tannins content was lower in Manfaloty peels and Edkawy juice than those of the other cultivars. Generally, there is a similarity between the distribution of total tannins and total phenolic content in the different parts of the four cultivars under study.

It can be concluded from the previous data that the bioactive compounds of pomegranate fruits vary considerably among cultivars. Peels are considered as a good source of polyphenolic compounds. Generally, dark red colour peels and juice were responsible for the major polyphenolic compounds content of pomegranate fruits. This is an advice to the consumers to buy pomegranate fruits with a dark red colour peels, to gain the beneficial health effects of this type of fruit. 

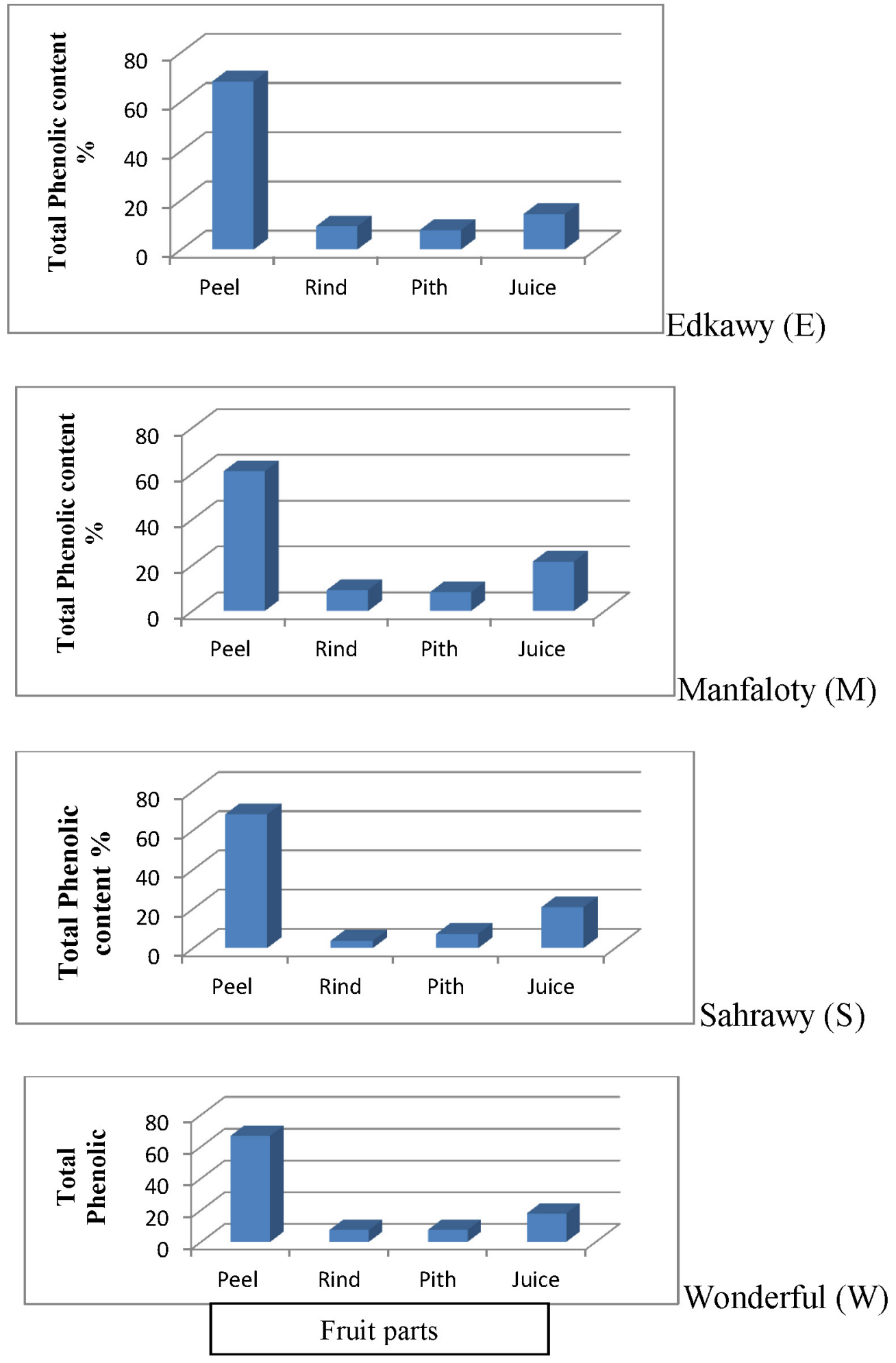

Fig 3: Distribution of total phenolics content in fruit parts of Edkawy (E), Manfaloty (M), Sahrawy (S) and Wonderful ( W) pomegranate cultivars 

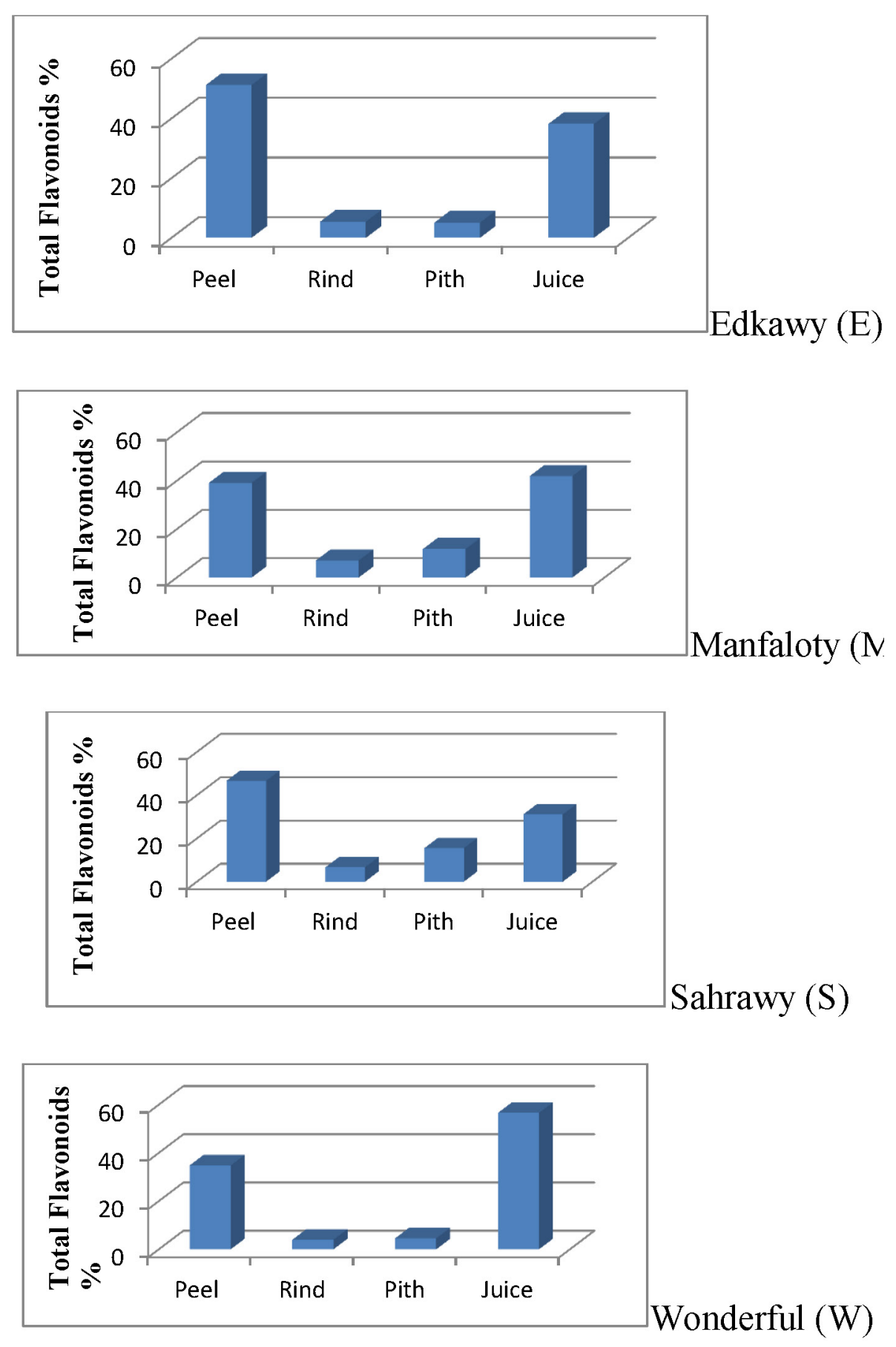

Fruit parts

Fig 4: Distribution of total flavonoids in fruit parts of Edkawy (E), Manfaloty (M), Sahrawy (S) and Wonderful ( W) pomegranate cultivars. 

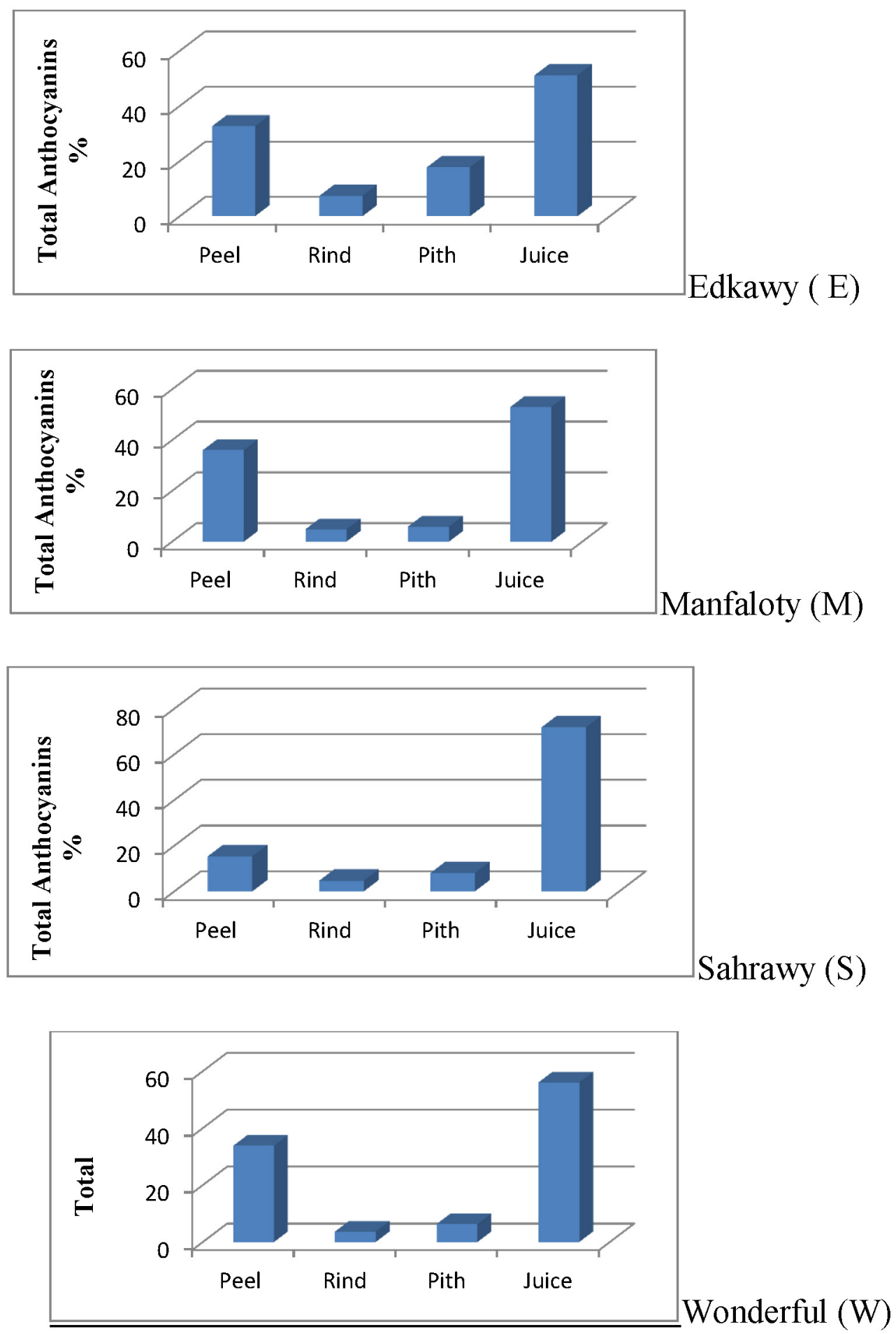

Fruit parts

Fig 5: Distribution of total anthocyanins in fruit parts of Edkawy (E), Manfaloty (M), Sahrawy (S) and Wonderful ( W) pomegranate cultivars. 

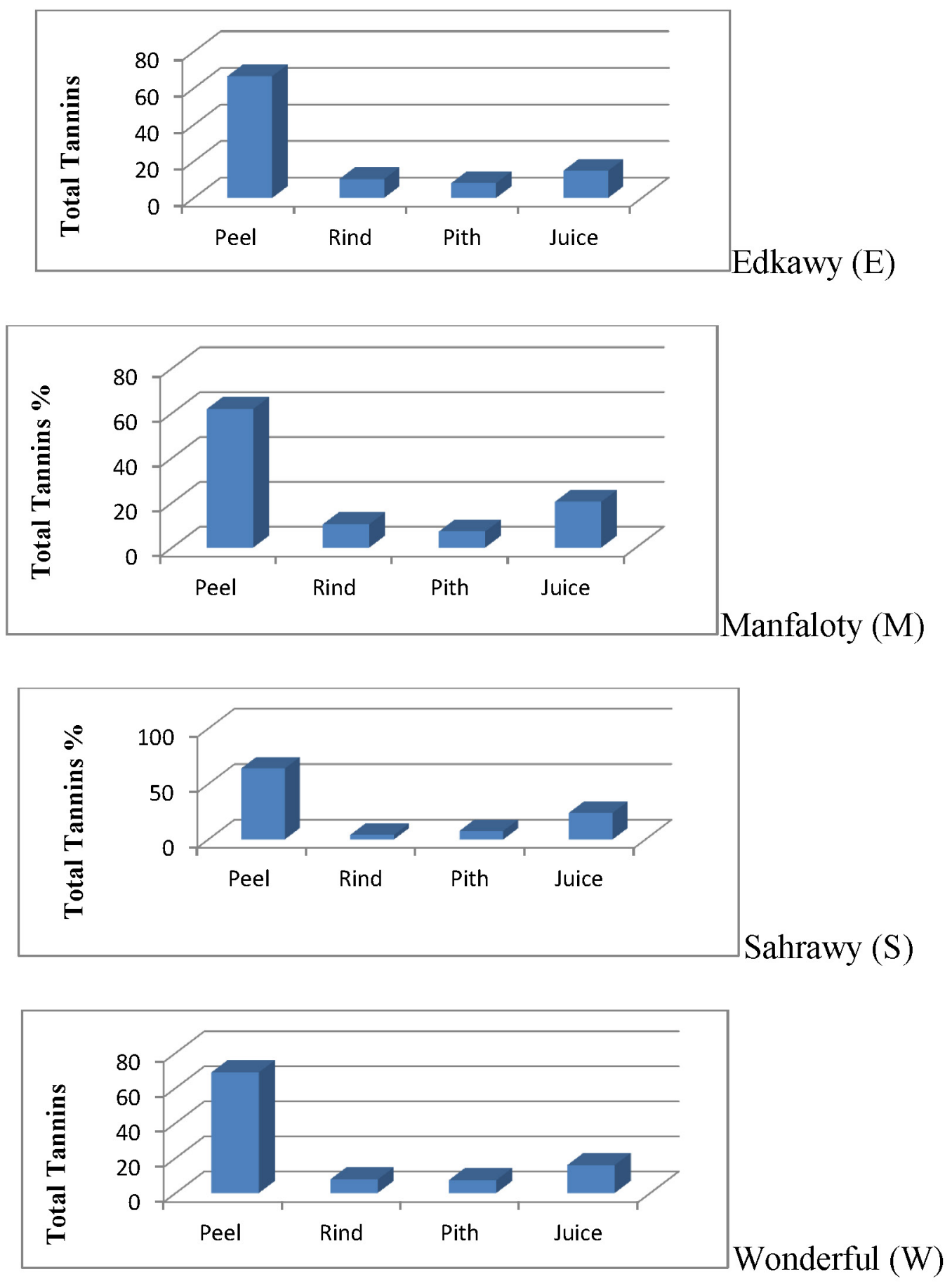

Fruit parts

Fig 6: Distribution of total tannins in fruit parts of Edkawy (E), Manfaloty (M), Sahrawy (S) and Wonderful ( $W$ ) pomegranate cultivars. 


\section{REFERANCES}

Abdel-Latif, E.M. 2000. New Untraditional Products from Pomegranate Fruits. In: "Symposium on Food Additives". International Center for Research and Consultation and Food Technology Research and Scientific Society of Food Industries. 10-11 May, Alex. Egypt.

Agriculture Directorates 2016. Agriculture Statistics Informal. Part two. Summer and Nile crops. Economic Affairs Sector. Agriculture Ministry. Egypt. pp: 265 - 275.

Akbarpour, V., Hemmati, K. \& Sharifani, M. 2009. Physical and chemical properties of pomegranate (Punica granatum L.) fruit in maturation stage. American Eurasian Journal of Agriculture. Environ Science, 6: 411-416.

AOAC. 2000. Association of Official Analytical Chemists. Official Methods of Analysis. 17 th Ed. Washington.

Cadze, J.S., Voca, S. \& Cmelik, Z. 2011. Physicochemical characteristics of main pomegranate (Punica granatum L.) cultivars grown in Dalmatia region of Coratia. Journal of Applied Botany and Food Quality, 85: 202-206.

Drogoudi, P.D. and Tispouridis, M. 2005. Physical and chemical characteristics of pomegranate. HortScience, 40: 1200-1203.

El-Maghrapi, L.A. 2003. Chemical and Technological Studies on Drying, Concentration and Preservation of Pomegranate Fruit Products. $\mathrm{Ph}$. D. Thesis Faculty of Agriculture, Cairo University, Egypt.

El-Nemr, S.E., Esmail, I. A. \& Ragab, M. 1990. Chemical composition of juice and seeds of pomegranate fruit. Die Nahrug, 34: 601-606.

El-Said, F.A., Opara,L.V. \& Al-Yahyai, R.A. 2009. Physicochemical and textural quality attributes of pomegranate cultivars (Punica geanatum L.) grown in the Saltana of Oman. Journal of Food Engineering, 90:129-134.

Fawole, O.A., Opara, U.L. \& Theron, K.I. 2012. Chemical and phytochemical properties and antioxidant activities of three pomegranate cultivars grown in South Africa. Food and Bioprocess Technology, 5: 425-444.

Ferrari, G., Glancaspro, A., Mazzeo, A., Giove, S.L., Matarrese, A.M.S \& Pacucci, C. 2014. Characterization of pomegranate (Punica granatum L.) genotype collected in Puglia region, South eastern Italy. Scientia Horticulturae, 178: 70-78.

Hmid,I., Elothmani,D., Hanine,H., Oukabli,A. \& Mehinagic,E. 2013. Comparative study of phenolic compounds and their antioxidant attributes of eighteen pomegranate (Punica granatum L.) cultivars grown in Morocco. Arabian Journal of Chemistry. Available on line, http : // dx.doi.org/ 10.1016 / j. arabjc. 2013.10.011

Humeida, M.A. and Hobani, A.I. 1993. Physical properties of pomegranate fruits. Journal of King Saud University, Agriculture Sciences, 5:165-175.

Lansky, E.P. and Newman, R.A. 2007. Punica granatum (pomegranate) and its potential for prevention and treatment of inflammation and cancer. Journal of Ethnopharmacol, 109: 177-206.

Ismail,A.I., Somia, A.H., Nehal, R.A. \& Shafika, A.Z. 2014. The physicochemical properties of pomegranate (Punica granatum L.) juice extracted from two Egyptian varieties. World Journal of Dairy and Food Sciences, 9: 29-35.

Ismail, O.M., Ibrahim, A.M. \& Rania, A.A. 2014. Morphological and molecular evaluation of some Egyptian pomegranate cultivars. African Journal of Biotechnology, 13: 226-237.

Martinez, J.J., Hernandez, F., Legue, P. \& R. Martinez, R. 2012. Physicochemical characterization of six pomegranate cultivars from Moracco: processing and fresh market aptitudes. Science of Horticulture, 140:100-106.

Mphahlele, R.R., Fawole, O.A., Mokwena,L.M. \& Opara,U.L. 2016. Effects of extraction method on chemical, volatile composition and antioxidant properties of pomegranate juice. South African Journal of Botany, 103: 135-144.

Ozgen. M., Durgac, C., Scrce, S. \& Kaya, C., 2008. Chemical and antioxidant properties of pomegranate cultivars grown in the Mediterranean region of Turkey. Food Chemistry, 111: 703-706.

Patil, U.S., Bandawane, D.D., Bibave, K.H. \& Chaudhari, P.D. 2014. Anti-hyperglycemic and in-vitro antioxidant activities of Punica granatum L.in alloxan induced diabetic rats. Ind Drugs, 50 : 39-46. 
Radunic, M., Spika, M.J., Ban, S.G., Cadze, I., Diaz-perez, J.C. \& Maclean, D. 2015. Physical and chemical properties of pomegranate fruit accessions from Croatia. Food Chemistry, 77: 53-60.

Shady, H.H. 2003. Physical, Chemical and Technological Studies on Pomegranate and the Juice Product. MSc. Thesis. Faculty of Agriculture. Alexandria University.

Singleton,V.L., Joseph,A. \& Rossi,J.R. 1965. Colorometry of total phenolics with phosphomolybdic- phosphotungstic acid reagents. American Journal of Enology and Vticulture, 16: 144-153.

Steel, R.G.D., and Torrie,J.H. 1980. Principals and Procedures of Statistics. London. McGraw Hill.
Tyagi, P., Singh, A., Bhardwaj, P., Sahu, S., Yadav, A.P. \& kori, M.L. 2012. Punicalagins-A, large polyphenol compounds found in pomegranates: A Therapeutic Review. Academic Journal of Plant Science, 5: 45-49.

Viladomiu, M., Hontecillas, R, L,.P. \& BasseganyaRiera,J. 2013. Preventive and prophylactic mechanisms of action of pomegranate bioactive compounds. Evid-Based Complement Alternative Medicine, 1:1-3.

Wetzstein, H., Zhang,Z., Ravid, N. \& Wetzstein, M.E. 2011. Characterization attributes related to fruit size in pomegranate. Hort Science, 46:908-912.

\title{
الخواص الطبيعية و المكونات النشطة حيوياً لأربعة أصناف لثمار الرمان المزروعة في مصر
}

\author{
فاتن فاروق عبد السلام ، ، يحيى جمال الدين محرم، عصمت صابر الزلاقى
}

قسى علوم و تقنية الأغذية ، كلية الزراعة ، جامعة الأسكندرية ، الشاطبى ، 0 ، إب، الإسكندرية ،

$$
\cdot \varepsilon \cdot \boldsymbol{R} \cdot \boldsymbol{c}
$$

أجريت هذة الدراسة على أربعة أصناف من ثمار الرمان- ثلاثة منها من الأصناف المصرية التقليدية

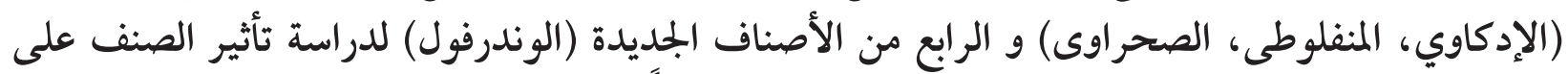

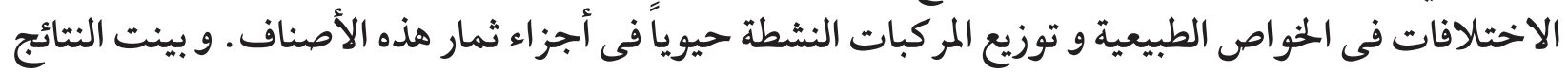

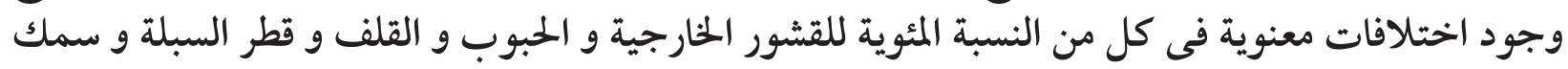

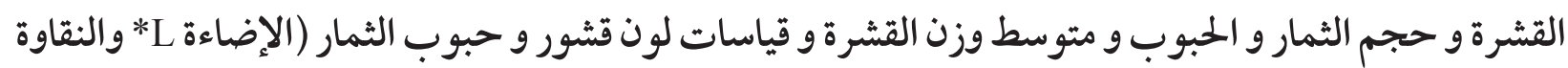
C و زاوية اللون h) · و و تميزت قشتور الثمار عامة بإرتفاع محتو اها من كل من الفينولات الكلية و التانينات الكلية

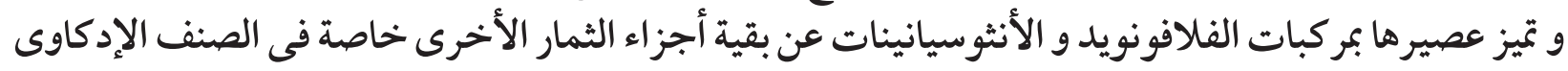
مقارنة ببقية الأصناف الأخرى. 